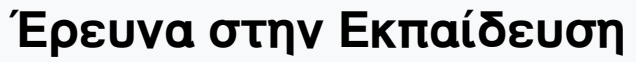

Tó $\mu .1$, Ap. 1 (2013)

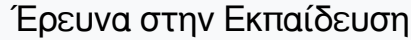

$155 \mathrm{~N} 2241.7303$

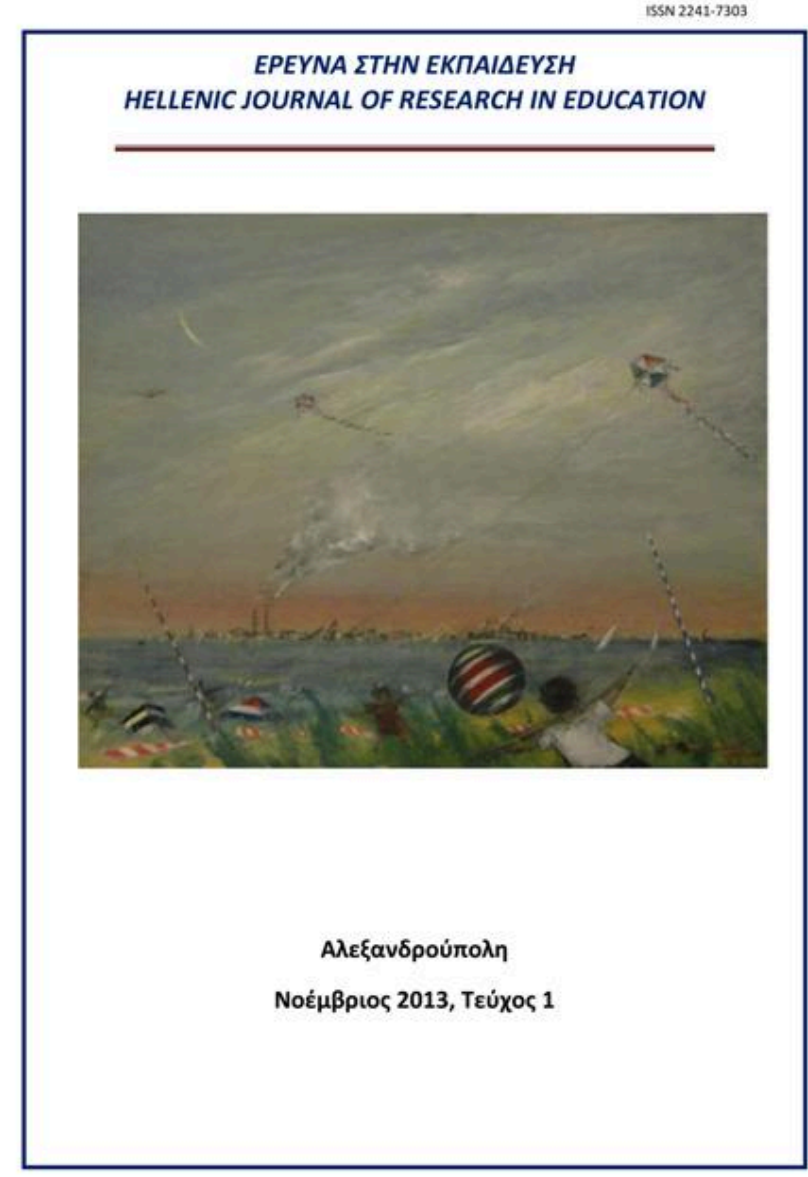

Classroom behavior management practices in kindergarten classrooms: An observation study.

Eleftheria Beazidou, Kafenia Botsoglou, Eleni Andreou

doi: $\underline{10.12681 / \text { hire.8794 }}$

Copyright $\odot$ 2015, Eleftheria Beazidou, Kafenia Botsoglou, Eleni Andreou

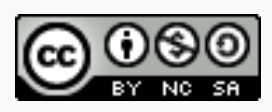

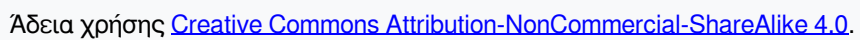

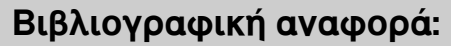

Beazidou, E., Botsoglou, K., \& Andreou, E. (2013). Classroom behavior management practices in kindergarten

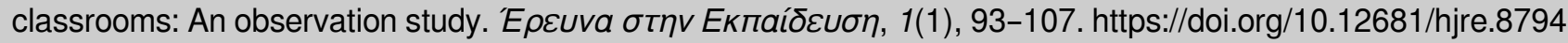




\title{
Classroom behavior management practices in kindergarten classrooms: An observation study.
}

\author{
Beazidou Eleftheria ${ }^{1}$, Botsoglou Kafenia ${ }^{2}$, Eleni Andreou ${ }^{3}$
}

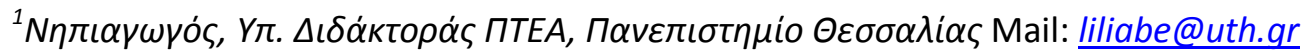

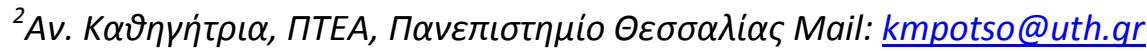

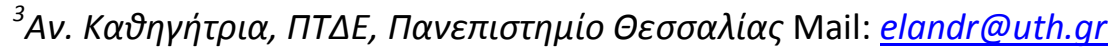

\begin{abstract}
The main purpose of this paper is to demonstrate the types of management practices that teachers use when disturbing behaviors occur in their classrooms. Teachers and children were observed in 14 kindergartens during daily classroom activities. Data was collected through the use of observation checklists, documents, and teacher's short interviews. The present study distinguishes the classroom management practices into two broad categories: positive non - punitive practices and negative punitive practices. The results showed that teachers combine most of the non - punitive practices such as, establishing and re-establishing rules, encouraging children to be responsible, promoting students to discuss a topic involving behavior, emotions or situations of concern, etc., with punitive practices such as verbal reprimand, intervention by yelling etc. Research has yielded important information that has practical implications for the improvement of classroom behavior management practices.
\end{abstract}

Keywords: management practices; kindergarten; disturbing behaviors.

\section{Introduction}

Classroom behavior is one of the trickiest issues teachers face today because classrooms are much more complicated than they were in the previous years, more students come to school with behavioral problems than ever before and teachers face the challenge of managing their behavior. The most common behavior problems for three- and fouryears-old are impulsivity, hyperactivity, and aggression. Approximately $10 \%-20 \%$ of preschoolers have been shown to exhibit these behaviors at significant levels either at home or at preschool (Powell, Fixsen, \& Dunlap, 2003). Challenging behavior in the classroom most often takes the form of disrupted sleeping and eating routines, physical and verbal aggression, property destruction, severe tantrums, self-injury, noncompliance, and withdrawal (Smith \& Fox, 2003). In most cases the problems the teacher faces in the classroom are due to a) The school's inability to meet the student's needs and, b) In 
adequate student's socialization (Matsagouras, 2001). As for preschool classes, Gouriotou (2008) suggests that the child's social behavior can be affected (positively or negatively) by the general ambience of the kindergarten classroom. This includes the organization of the kindergarten environment, the curriculum, the attitude that teacher presents towards the variety of behaviors, and the family - kindergarten relation.

It's true that no matter how good a teacher or his/her students may be, there may always arise circumstances that call for management either at personal or classroom level (Matsagouras, 2001). The most current approaches to the topic are derived from two primary considerations: a) classroom discipline is not an individual problem but a collective one. For this reason classroom management cannot focus on the individual case, but must attend to the proper functioning of the class, and b) instructional processes require rules related to classroom functioning and general social order. Lang and Hebert (1995) suggest that effective classroom management involves effective instruction. Teacher's instruction within the classroom, aid at the acquisition of student's both academic and non - academic skills. Classroom management has been defined broadly as any action a teacher takes to create an environment that supports and facilitates both academic and social-emotional learning (Evertson \& Weinstein, 2006). However, effective classroom management provides students with opportunities to socialize while learning.

Recently, a systematic best evidence review was conducted to identify evidencebased practices in classroom management to inform research and practice (Simonsen, Fairbanks, Briesch, Myers, \& Sugai, 2008). Results of the evaluation of 81 studies identified 20 general practices that met the criteria for evidence-based practices. These 20 general practices that teachers use fell into five broad categories: (1) maximize structure and predictability; (2) post, teach, review, and provide feedback on expectations; (3) actively engage students in observable ways; (4) use a continuum of strategies to acknowledge appropriate behavior, and (5) use a continuum of strategies to respond to inappropriate behavior (Simonsen, et. al., 2008). Also, Lewis, Romi, Katz, and Qui (2008); Lewis, Roache, and Romi, (2011) suggest that teachers use six categories of discipline practices, including: Rewarding, Punishing, Involvement in decision-making, Discussion and Negotiation, Hinting, and Aggression. Additionally, combinations of one or more of these strategies comprise most of the available approaches to discipline (Charles, 2008; Tauber, 2007).

Most of early childhood teachers safeguard an exciting, enjoyable, secure environment and create positive relationships in their classrooms because they know that teachers who are warm and attentive and who engage and encourage children, build strong 
relationships with children and minimize misbehaviors in their classrooms. Edwards and Raikes (2002) suggest that positive relationships between early childhood educators and children provide a potential classroom management tool. Also, according to Kostelnik, Soderman, and Whiren (1993) structuring a positive classroom climate is essential in creating learning contexts in which children build a strong sense of being valued, confident, and competent. Another important factor in effective classroom management is bonding within the group, which will help children to adopt values like cooperation, mutual help, respect, and communication. All the above result in lower incidents of negative behavior as well as antisocial tendencies, and add to socially acceptable behavior. It is known that rules and clear expectations are components of effective behavior management in kindergarten classrooms. According to Jones and Jones (2001) there are certain factors that increase the likelihood of successful classroom rules in early childhood: 1 . Students need to be involved in developing rules, 2 . rules should be clearly stated, 3. as few as possible rules should be developed, 4. students should state their acceptance of the rules in a formal way. Lucid expectations entail knowing what to do and when to do it (Vacca \& Bagdi, 2005) and make children feel comfortable and secure in kindergarten. Walker, Shea, and Bauer (2007) suggest practices which are based on the development of a student's self-control and supportability of a teacher's confidence. So, students become independent and gradually internalize procedures, daily routines and rules. Many kindergarten teachers focus on social - emotional education and proactive objectives which, according to Hawkins, Catalano, and Brewer, (1995: 56) are:

- Stimulation of control and behavior through self-control ("stop and calm down")

- Development of effective vocabulary and emotions for better understanding of oneself and others.

- Mastering emotional, cognitive, and verbal skills necessary in solving social problems, and

- Enhancement of positive self-esteem and efficient social relationships.

Many different types of behavior management strategies are grouped in two categories: positive and restrictive strategies. Positive strategies were defined as teacher behaviors that involve aspects of reward, positive reinforcement etc. Restrictive strategies were defined as teacher behaviors that include aspects of punishment, negative reinforcement, chastisement, etc. 
Effective classroom management strategies have been shown to positively affect several factors such as school achievement (Wang, Haertel, \& Walberg, 1993) schoolwork attitudes (Lewis, Romi, Katz, \& Qui, 2008) social competence among peers (WebsterStratton, Reid, \& Stoolmiller, 2008) and general emotional-behavioral functioning (Piko, Fitzpatrick, \& Wright, 2005). Classroom management is directly tied to levels of student involvement and academic achievement, in that it can help to decrease disruptive classroom behaviors and increase student engagement in academic tasks. Poor classroom management has been linked to long-term negative academic, behavioral, and social outcomes for students (Reinke \& Herman, 2002).

\section{Research Questions}

Although there is a plethora of literature designating effective classroom management strategies, little is known about early childhood classroom management practices. Evertson and Weinstein (2006) comment in their book: "virtually, all of the classroom research related to management has been conducted in upper higher elementary school classrooms. Only few works had been done on classroom management in early childhood education" (p. 375). However, more studies are needed to determine what early childhood educators are currently doing in order to manage disturbing behaviors in their classrooms. Therefore, we decided to conduct research in order to evaluate classroom management behavior practices in kindergarten distinguishing the positive from negative types of practices.

The following research questions were addressed in this study: In classroom procedures, what practices do teachers prefer to apply for managing inappropriate behaviors? What components make up a successful classroom management program? Do positive classroom management practices occur more frequently than negative ones?

\section{Method}

\section{Participants}

Observations were made in 14 kindergarten classrooms (One classroom in 14 correspondent schools). After appropriate training, two datacollectors observed each classroom on one daily school program during the spring of the year 2011 in a mediumsized city of Greece, Volos. Totally 168 students participated in the research and the mean number of students per classroom was 16 with a range of 14 to 22 students aged 4 and 5 years. The teaching experience of participating teachers ranged from five years to more than 
20 years. All teachers had a university degree; two of them had a master in education and seven of them attended seminars organized by School Counselors. Moreover, all teachers were female and worked in a public school. The researcher sought permission from the branch director and the teachers had the choice to participate or not in the study.

\section{Materials and procedure}

In order to create a list of practices that teachers use in their classrooms we searched the relative literature. Online database searches included ERIC, PsycINFO, Scholar Google, keyword searches, were conducted in order to identify eligible practices. Finally, we designed a checklist to illustrate the types of classroom management practices based on the approach of Lewis, Roache, and Romi (Lewis, et. al., 2011). We categorized all behavior management practices in six categories. The first category includes practices which focus on recognizing children's appropriate behavior, the second category on punishing students who misbehave, the third category on talking with students to discuss the impact of their behavior on others, the forth category on involving students in classroom discipline decision-making, the fifth category on hinting. Finally, the sixth category includes practices which focus on aggressive techniques. Two of the above categories include negative punitive practices and the others include positive non-punitive, ones. For the economy of space we present a small part of the checklist:

TEACHER INVOLVES STUDENTS IN CLASSROOM DISCIPLINE DECISION-MAKING

Teacher set consistent limits

Teacher post the rules in several places

Teacher communicates clear expectation....etc.

The observers should distinguish between the identified and non-identified practices.

\section{Data collections and analysis}

Two data collectors observed the management practices applied by teachers throughout the daily school program. Participant teachers were not asked to 'do' anything outside their everyday practice. The observation period began with data collection on the visible practices of each classroom. Classroom social behavior was the focus of the observations and in particular, the teacher's verbal and nonverbal statements and their actions and behaviors in response to children's misbehaviors. A child's disturbing behavior defined as beginning with an initiating event and terminating when the child left to pursue a new activity. Also, observers had to provide evidence to support each category of classroom behavior management practices. Following each observation period the observers had a 
meeting and a short interview with the classroom teacher in order to collect more information. So, the data was collected through the use of the observation checklist, documents and teacher's short interviews.

The reliability of the data was estimated by an independent coder who compared each code of the two observers with the characterization agree or disagree. Measurement of the extent to which data collectors assign the same score to the same variable is called interrater. While there have been a variety of methods to measure interrater reliability, traditionally it was measured as percent agreement, calculated as the number of agreement scores divided by the total number of scores (agreement scores + disagreement scores). The agreement level between the observers was very strong (92\%).

We counted the number of observations for each domain classroom management practice (teacher recognize the appropriate behavior, teacher punish students who misbehave, teacher use aggressive techniques, teacher talk with students to discuss the impact of their behavior on others, teacher involve students in classroom discipline decisionmaking, and teacher give non-directional descriptions). Then, we transferred the number of observations in a seven-point scale (from 0 to 7). The ratings were: $0=$ Exemplar is not evident -7 = Exemplar is high evident. Each rating indicated the frequency of each domain practice. $0=$ Exemplar is not evident approximately $0-10 \%$ of the total observation, $1=$ approximately $25 \%$ of the total observation, $2=$ approximately $35 \%$ of the total observation, $3=$ approximately $45 \%$ of the total observation, $4=$ approximately $55 \%$ of the total observation, $5=$ approximately $65 \%$ of the total observation, $6=$ approximately $75 \%$ of the total observation, $7=$ approximately $75-100 \%$ of the total observation.

Data were subjected to a range of descriptive analyses in SPSS. The high mean scores indicated the most common practices in classrooms.

\section{Results}

In order to answer the question: "what practices do the teachers prefer to apply for managing inappropriate behaviors in their classrooms?" data analysis indicated the total frequency of the domain behavior management practices that teachers used throughout a day: Teachers moderately to highly evident vón $\mu \alpha$ ? $(M=5.3 S D=1.7)$ involve students in classroom discipline decision-making, rarely evident $(M=3.0 \quad S D=1.0)$ recognize the appropriate behavior in their classrooms, almost rarely evident $(M=2.6 S D=2.3)$ talk with students for the misbehaving behavior, almost moderately evident ( $M=4.6 S D=1.4)$ give nondirectional descriptions, almost moderately evident $(M=4.1 S D=1.2)$ teachers use aggressive 
techniques and least often evident ( $M=2.7 S D=1.4)$ teachers punish students who misbehave (table 1). The findings indicated that there is no statistical deference $(t=, 944, d f=13,2$ tailer=,362 between total mean punitive practices $(M=3,46 \quad S D=1,40)$ and total mean nonpunitive practices $(M=3,90 \quad S D=1,40)$. In other words, all teachers in their classrooms combine non punitive and punitive behavior management practices. Although most teachers use rules and clear expectations in their classrooms they also, use verbal reprimands, hints, time out etc.

In order to have a more comprehensive idea about components making up the classroom management programs, we present examples of practices which were collected by the analysis of documents and follow-up discussions. Classroom rules define acceptable behaviors and provide clearly defined expectations. We observed a large number of teachers establish and re-establish social behavior rules of basic etiquette (e.g. "not allowed to make physical contact with another person without his/her permission"). Also, we noted that many teachers had named the behavioral rules as 'moral contract', because rules are a deal between the teacher and children. Many teachers in our study post a chart of the basic behavior rules with a space to check off next to each student's name when he or she obeys the rules (columns for rules, rows for students' names). Also, they put stars in the squares of the chart. If a student complies with classroom rules, he or she earns or loses stars. Some teachers use pictures to display rules. During the daily program, teachers repeatedly remind the children about the rules. For example, "A child requests and receives assistance from another child while he was building a bridge with wooden blocks. Another child of peer team mocks the child who received assistance using swear-words. The fight had just begun; the teacher responded by showing the rule "getting help" and giving more details and explanations about this rule...."

Many teachers reward students in many ways e.g. verbally, non-verbally, by giving privileges, stars or stickers, through positive motions or praising the child's accomplishments. 
Many times, teachers ignore the unacceptable behaviors and recognize a successful attempt for acceptable behaviors. Most often, teachers tackle the behavior problems through group discussions. Teachers, who utilized discussions, point out inner thoughts,

\begin{tabular}{|c|c|c|c|c|c|c|}
\hline $\begin{array}{l}\text { Broad } \\
\text { categories }\end{array}$ & $\begin{array}{l}\text { Domain practices } \\
\text { of classroom } \\
\text { behavior } \\
\text { management }\end{array}$ & Items & $M$ & SD & \multicolumn{2}{|c|}{ Min/Max } \\
\hline $\begin{array}{l}\text { Non } \\
\text { punitive }\end{array}$ & $\begin{array}{l}\text { Recognize the } \\
\text { appropriate } \\
\text { behavior }\end{array}$ & $\begin{array}{ll}\text { - } & \text { Rewards } \\
\text { - } & \text { Verbal praise } \\
\text { - } & \text { Positive touching }\end{array}$ & 3.0 & 1.0 & 1 & 7 \\
\hline punitive & $\begin{array}{l}\text { Punish students } \\
\text { who misbehave }\end{array}$ & $\begin{array}{l}\text { - } \quad \text { Assigning extra work } \\
\text { - } \quad \text { Time out } \\
\text { - } \quad \text { change seat }\end{array}$ & 2.7 & 1.4 & 1 & 5 \\
\hline punitive & $\begin{array}{l}\text { Use aggressive } \\
\text { techniques }\end{array}$ & 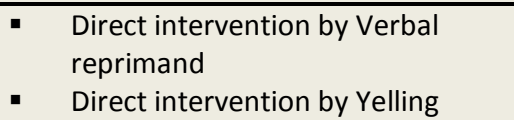 & 4.1 & 1.2 & 1 & 5 \\
\hline $\begin{array}{l}\text { Non } \\
\text { punitive }\end{array}$ & $\begin{array}{l}\text { Talk with students } \\
\text { to discuss the } \\
\text { impact of their } \\
\text { behavior on } \\
\text { others, }\end{array}$ & $\begin{array}{l}\text { Discussions. Emphasizing } \\
\text { - a)cooperative skills } \\
\text { - } \quad \text { b) problem - solving skills } \\
\text { - } \quad \text { c)self-regulation skills } \\
\text { Use literature, puppets to expand } \\
\text { the discussion }\end{array}$ & 2.6 & 2.3 & 1 & 7 \\
\hline $\begin{array}{l}\text { Non } \\
\text { punitive }\end{array}$ & $\begin{array}{l}\text { Involve students in } \\
\text { classroom } \\
\text { discipline decision- } \\
\text { making }\end{array}$ & $\begin{array}{l}\text { - } \quad \text { Set consistent limits } \\
\text { - } \quad \text { Communicate Clear expectation } \\
\text { - } \quad \text { Establishing-re-Establishing rules } \\
\text { - } \quad \text { Post the rules in several places } \\
\text { and demonstrate them }\end{array}$ & 5.3 & 1.7 & 3 & 7 \\
\hline $\begin{array}{l}\text { Non } \\
\text { punitive }\end{array}$ & $\begin{array}{l}\text { Give non- } \\
\text { directional } \\
\text { descriptions }\end{array}$ & 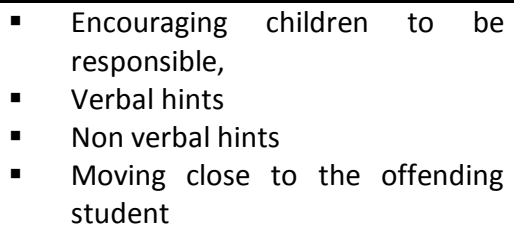 & 4.6 & 1.4 & 3 & 7 \\
\hline
\end{tabular}

Table 1 The frequency of classroom management practices that teachers use in their classroom

feelings, and emotions of the misbehaving child and all classmates. For example, "Students work in groups and discuss alternative behaviors to inappropriate ones. Both the misbehaving and the hurting child are encouraged to express their feelings and their opinions on the event. The teacher uses open-ended questions helping the discussion including the other children as well. The teacher says 'all participants in our class want to hear what happened to you in the block center. What might happen if ...?, What would you do if ...?, or How would you feel if ...?.' All children are encouraged by the teacher to state their opinions without any criticism or discrimination".

Another teacher focuses on feelings generated by disturbing behavior: "George, you seem to be very upset right now. First, you pushed your classmate while I was talking. Second, think of the effects your behavior had on me and the other students. You see, we 
had to stop what we were doing and your classmate is very angry" Afterwards, the student is informed about the feelings he generated not only in the teacher but also in the other students. This practice educates children in many ways and provides effective opportunities for them to learn pro social skills, cooperative skills, problem solving skills, empathy etc.

Most teachers use verbal and non-verbal hints aimed at stimulating student's responsibility. For example, the teacher is moving closer to the child and uses a verbal hint. "What are you doing? I'm afraid that someone may want to be punished...". We suppose that the teacher expects the child to stop his unacceptable behavior. Responsibility is a key word in the classroom. Teachers play an important role in helping students become more responsible, interpersonally and personally. They mainly reinforce self-esteem through simple classroom tasks. Many teachers help misbehaving students to stop their unacceptable behavior by encouraging them to become a 'teacher's assistant'. For example, "A child is assigned to protect the rights of all his classmates. Another misbehaving child is assigned the responsibility of selecting and checking out library materials."

On the other hand, the observations show that many teachers use punitive practices. Teachers use the most potent punishment available in a desperate effort to control an individual behavior and make it clear to other children that acting in such a way is not tolerated. Most teachers keep the misbehaving child busy with extra work so that the child has less time and means to behave inappropriately. Also, a great number of teachers punish students who misbehave utilizing "Time out". They remove the child from the activity, but not from the room. Some of them immediately remove students who misbehave from the activity space to a "cool - down area", which is a place for students to reflect and refocus on their behaviors for a specific amount of time. Some teachers use disapproving verbal statements as a form of punishment to alter disturbing behavior. Reprimands include any attempt to correct the inappropriate behavior through verbal statements. Teachers tend to rely on them because they are relatively easy to administer. A reprimand can be a punishment if it is considered unpleasant enough and corrects the behavior in question. In our study, reprimands were backed up with yelling, moving the student closer to the teacher and sometimes with time-out.

\section{Discussion}

Literacy indicated that teacher's responses and classroom procedures differ from classroom to classroom depending on the personal consideration of a teacher (Martin, Yin \& Baldwin, 1998), personal beliefs, personal orientation, and scientific qualification (Agne, 
Greenwood, \& Miller, 1994). They employ and use strategies that have been proved to be effective and work in their particular situation with their particular students (Lavoritano \& Segal, 1992). Research referring to teacher's management practices has shown that teachers tend to employ a variety of techniques. The findings of the present study indicated the most common behavior management practices that kindergarten teachers use in Greek public schools. These results extend the findings of previous studies which reported that teachers tend to use positive ways of dealing with children's behavior problems, but they do deliver punishment as well (Docking, 1980; Papatheodorou, 2000) Many explanations could be given for the results. Teachers do not have enough information and understanding about how management practices should be used (Martin, Linfoot, \& Stephenson, 1999). It is notable that some teachers are inadequately trained to deal with students with behavior problems and may actually exacerbate the misbehavior (Pettit, Bates, \& Dodge, 1993). Papatheodorou (2000) says that in the context of teacher training in Greece, classroom behavior management has not yet been identified as an issue for particular consideration and study. Merrett and Tang (1994) support the view that teachers teach the way they remember being taught themselves and they go on using traditional sanctions. Thus, in the classroom, a teacher may come to use techniques which have been developed through experience and by trial and error processes.

More specifically our findings show, that a significant number of teachers think that rules are necessary in their classrooms. Previous research has supported the use of rules which constitute the most cost-effective form of classroom management (Bicard, 2000). Moreover, teachers who create positive rules as a basis for their classroom management system, create a positive environment that facilitates rule-following behavior and helps minimize negative cycles of inappropriate behavior by shifting teacher attention from inappropriate to appropriate student behavior (Gunter, Denny, Jack, \& Shores, 1993).

Very often teachers recognize that praise and reward make the students feel good about themselves and the overall aim of praise and reward is for the benefit of a child. Our results are consistent with a considerable body of research that points to the value of using praise as effective management practice (Merrett \& Wheldall, 1986). On the other hand, we found some researchers who suggest that praise and reward are not always positive and the use of praise or rewards does not make children feel supported but evaluated and judged (Curry \& Johnson, 1990; Kohn, 1994). Although praise and rewards can kill student's intrinsic motivation, many meta-analytic reviews have identified several conditions under which praise and rewards can be used to maintain or enhance intrinsic motivation 
(Cameron, Banko \& Pierce, 2001). So, praise and reward must be given with special care to ensure they do not have a negative influence.

There were some teachers in our sample who prefer to manage children's behaviors by employing discussions which include teaching of pro social and cooperative skills. It is true that children with higher levels of pro social behaviors typically engage in lower levels of aggression (Crick, Casas, \& Mosher, 1997). Teachers promote individual student's control over behavior whenever possible, but more often place the needs of the group as a whole over the needs of individual students. This practice not only pertains to comprehension, but also addresses anger management and solutions to the problems. This practice improves children's personal skills in managing strong emotion such as empathy, effective communication and conflict management skills (Nemec \& Roffey, 2005). Also, previous research showed that teachers who respect children's feelings see social difficulties as opportunities for teaching, and modeling social competence and sincerity through social interactions (Katz \& McClellan, 1997). Although learning social emotional skills through discussion is an effective practice, our results indicated that a number of teachers have certain doubts about their effectiveness. One explanation may be that most teachers want immediately to stop the inappropriate behavior in order to continue all routines and activities of the daily program. Another explanation may be that many teachers have neither patience nor knowledge to come up with possible ways of solving the problems together with children. Some of them believe that teaching emotions and feelings is out of their control as Sutton (2005) suggests saying that "emotions have often been thought of as out of control.." (p. 229). However, this practice has long-term effects on classroom management promoting the social and emotional competence of children.

Very often teachers use other strategies that are not recognized as being effective in managing misbehavior. They most often yell and use verbal reprimands. These practices used by teachers, probably to have short- term control in the classroom avoid the problem, or give solutions to children without the necessary intention of changing their disturbing behavior. This practice may prove enough to eliminate the immediate problem and allow the teacher to continue teaching, but it creates more problems in the long run, e.g. the teacher/student interaction. Studies have shown that punishment can lead children to feel anger, defiance and want of revenge (Kohn, 1994). Also, previous studies demonstrated that punitive practices are the easy way of managing misbehaviors and many teachers employ verbal reprimands (Little \& Akin-Little, 2008). The child learns no positive alternative behavior and is likely to internalize a mix of negative emotions. These feelings certainly are 
not conducive to building a caring community or fostering social competence in children. In other words, the dispensing of punishment is another way of adults exercising their power over children (Moberly, Waddle, \& Duff, 2005).

\section{Conclusion}

The present study indicated that teachers manage misbehaviors by developing routines and reinforcing expectations. Also, they enhance responsibility and provide reinforcement and specific praise to students who follow the rules. In addition, they use verbal reprimands and other aggressive strategies, as well. These results give the teachers and social workers knowledge to manage disturbing behaviors by improving positive classroom management practices and help them to move away from the punishment approach.

\section{Limitations}

The sample of the present study was very small. Therefore, the results are not generalized. Also, the results indicate the most common management behavior practices, but there is no measure for their effectiveness.

\section{Reference}

Agne, K.J., Greenwood, G.E., \& Miller, L.D. (1994). Between teacher belief system and teacher effectiveness. The journal of research and development in Education, 27, (3), 141-152.

Bicard, D.F. (2000). Using classroom rules to construct behavior. Middle School Journal, 31, (5), 37-45.

Cameron, J., Banko, K. M., \& Pierce, W. D. (2001). Pervasive negative effects of rewards on intrinsic motivation: The myth continues. The Behavior Analyst, 24, 1-44.

Charles, C. (2008). Building Classroom Discipline: From models to practice, $\left(9^{\text {th }}\right.$ ed.) Merrill: Ohio.

Crick, N. R., Casas, J. F., \& Mosher, M. (1997). Relational and overt aggression in preschool. Developmental Psychology, 33, 579-588.

Curry, N. E. \& Johnson, C. J. (1990). Beyond self-esteem: Developing a genuine sense of human value., Washington, DC: National Association for the Education of Young Children.

Docking, J.W. (1980). Control and Discipline in schools. London: Harper and Row.

Edwards, C. P. \& Raikes, H. (2002). Extending the dance: Relationship-based approaches to infant/toddler care and education. Young Children, 57, 10-17. 
Evertson, C.,M. \& Weinstein, C.,S. (2006). Handbook of classroom management: research, practice, and contemporary issues, Mahwah, NJ: Lawrence Erlbaum Associates.

Gunter, P. L., Denny, R. K., Jack, S. L., \& Shores, R. E. (1993). Aversive stimuli in academic interactions between students with serious emotional disturbance and their teachers. Behavioral Disorders, 18, 265-274.

Gouriotou, E. (2008). «Aggressive behavior management in early childhood education». In New Educational resources - Assessment and Management of Education. (Eds. Georgogiannis, P.). Patras, 2008, pp. 356-365. (in Greek)

Hawkins, J. D., Catalano, R. F., \& Brewer, D. D. (1995). Preventing serious, violent, and chronic juvenile offending: Effective strategies from conception to age six. In J. C. Howell, B. Krisberg, J. D. Hawkins, \& J. J. Wilson (Eds.), A sourcebook: Serious, violent, and chronic juvenile offenders (pp. 47-60).Thousand Oaks, CA: Sage.

Jones, V. F. \& Jones, L. S. (2001). Comprehensive classroom management: Creating communities of support and solving problems (6th ed.). Boston: Allyn \& Bacon.

Katz, L.G. \& McClellan, D. E. (1997). Fostering children's social competence: The teacher's role. Washington, DC: National Association for the Education of Young Children.

Kohn, A. (1994). Bribes for behaving: Why behaviorism doesn't help children become good people. NAMTA journal, 19, (2), 71-94.

Kostelnik, M., Soderman, A. \& Whiren, A., (1993). Developmentally Appropriate Practices in Early Childhood Education. New York, NY: Macmillan Publishing Company.

Lang, R.H. \& Hebert, J. (1995). Teaching Strategies and Methods for Students Centered Instruction, America: H.M. Whinney.

Lavoritano, J. \& Segal, P. B. (1992), Evaluating the efficacy of a school counseling program. Psychol. Schs., 29, 61-70.

Lewis, R., Romi, S., Katz, Y.J. \& Qui, X. (2008). Students' reaction to classroom discipline in Australia, Israel and China. Teaching and teacher Education, 24, (3), 715-724.

Lewis, R., Roache, J. \& Romi, S. (2011). Coping styles as mediators of teachers' classroom management techniques. Research in education, 85, 53-68.

Little, S. G. \& Akin-Little, A. (2008). Classroom management, In W. T. O'Donohue and J. E. Fisher (Eds.), Cognitive behavior therapy: Applying empirically supported techniques in your practice ( $2^{\text {nd }}$ ed.) (pp. 75-82). Hoboken, NJ: Wiley. 
Martin, A. J., Linfoot, K. \& Stephenson, J. "How teachers respond to concerns about misbehavior in their classroom", Psychology in the Schools, vol. 36, no. 4, pp. 347$358,1999$.

Martin, N.K., Yin, Z. \& Baldwin, B. (1998). Construct validation of the attitudes and beliefs classroom control inventory. Journal of classroom interaction, 33, (2), 6-15.

Matsagouras, E., (2001). The school classroom. Athens: Grigoris. (in Greek)

Merrett, F. \& Wheldall, K. (1986). Observing Pupils and Teachers in Classrooms (OPTIC): behavioural observation schedule for use in schools. Educational Psychology, 6, 57-70.

Merrett, F., \& Tang, W.M. (1994). The attitudes of British primary school pupils to praise, rewards, punishments and reprimands. British Journal of Educational Psychology, 64, 91-103.

Moberly, D.A., Waddle, J.L. \& Duff, R. (2005). The use of rewards and punishment in early childhood classrooms. Journal of Early Childhood Teacher Education, 25, 359-366.

Nemec, M. \& Roffey, S. (2005). Emotional literacy and the case for a whole-school approach to promote sustainable educational change. Australian Association for Research in Education, www.aare.edu.au/05pap/nem05355.pdf. Retrieved 26/4/2011.

Papatheodorou, T. (2000) Management approaches employed by teachers to deal with children's behaviour problems in nursery classes. School Psychology International, $21(4), 415-440$.

Pettit, G.S., Bates, J.E. \& Dodge, K.A. (1993). Family interaction patterns and children's Conduct problems at home and school: A longitudinal perspective. School Psychology Review, 22, 403-420.

Piko, B.F., Fitzpatrick, K.M. \& Wright, D.R. (2005). A risk and protective factors framework for understanding youth's exteternalizing problem behavior in two different cultural settings. European Child \& Adolescent Psychiatry, 14, (2), 95-103.

Powell, D., Fixsen, D. \& Dunlap, G. (2003). Pathways to service utilizations: A synthesis of evidence relevant to young children with challenging behavior. Tampa, FL: University of South Florida, Center for Evidence-Based Practice: Young Children with Challenging Behavior.

Reinke, W. \& Herman, K. (2002). Creating school environments that deter antisocial behaviors in youth. Psychology in the Schools, 39, 549-559.

Simonsen, B., Fairbanks, S., Briesch, A., Myers, D., \& Sugai, G. (2008). Evidence-based practices in classroom management: Considerations for research to practice. Education and Treatment of Children, 31, 351-380. 
Smith, B. \& Fox, L. (2003). Systems of service delivery: A synthesis of evidence relevant to young children at risk of or who have challenging behavior. Tampa, FL: Center for Evidence-Based Practice: Young Children with Challenging Behavior, University of South Florida.

Sutton, R. E. (2005). Teachers' emotions and classroom effectiveness: Implications from recent research. The Clearing House, 78, (5), 229-234.

Tauber, R. T. (2007). Classroom Management: Sound Theory and Effective Practice (4th ed.). Greenwood Publishing Group, Inc.

Trovato, J., Harris, J., Pryor, C.W., \& Wilkinson, S.C.(1992). Teachers in regular classrooms: An applied setting for successful behavior programming. Psychol. Sch. 29, 52-61.

Vacca, J. \& Bagdi, A. (2005). Relationships for life: supporting the emotional health of infants and toddlers. Dimensions of early childhood, 33, (1).

Walker, J.E., Shea, T.M. \& Bauer, A.M. (2007). Expert from behavior management: A practical Approach for Educators ( $9^{\text {th }}$ ed), New York: Prentice Hall.

Wang, M.C., Haertel, G.D. \& Walberg, H.J. (1993). Toward a knowledge base for school learning. Review of Educational Research, 63, (3), 249-294.

Webster-Stratton, C., Reid, J. \& Stoolmiller, M. (2008). Preventing conduct problems and improving school readiness: evaluation of the incredible years teacher and child training programs in High- Risk Schools. Journal of Child Psychology and Psychiatry, 49, (5), 471-488. 